\title{
Wzmożona obecność języka wykluczającego w polskiej przestrzeni publicznej - alert dla pedagogów
}

Dante był odszczepieńcem i mistykiem, lecz słusznie postapił, rezerwując jeden z najgorętszych kręgów piekła dla tych, którzy próbujq pozostać neutralni w czasach moralnego kryzysu

Ch. Hitchens (List XVIII)

\begin{abstract}
STRESZCZENIE
Kultura jest nierozerwalnie związana z językiem; język jest rodzajem przewodnika kulturowego, ułatwia jej zrozumienie. Język jest zarówno spoiwem społeczeństwa, jak i narzędziem ekspresji, a dla jednostki potężnym czynnikiem rozwoju indywidualności. Stąd konieczność zainteresowania się przez pedagogów językiem - niewidzialnym środowiskiem edukacyjnym. Przestrzeń edukacji, analizowana tu przez pryzmat języka, pozostaje w ścisłym związku z przestrzenią publiczną, dlatego wgląd w sferę publiczną i dyskurs publiczny wydają się niezbędne.

Transformacja polskiego społeczeństwa w latach 90. XX wieku ujawniła jego wewnętrzną różnorodność i co się z tym wiąże - potrzebę znalezienia języka, który pozwoliłby na komunikację i opis nowej rzeczywistości bez ranienia kogokolwiek. Jednak zjawisko poprawności politycznej nie zyskało w Polsce akceptacji. Co więcej, szerzy się mowa nienawiści, język wykluczający różne kategorie społeczne. Jest to sygnał, który zachęca nas,
\end{abstract}

${ }^{1}$ Elżbieta Górnikowska-Zwolak, Wydział Etnologii i Nauk o Edukacji, Uniwersytet Śląski w Katowicach, Polska, e-mail: gornikowska@poczta.onet.pl, ORCID ID: https://orcid.org/00000002-0092-7880. 
pedagogów, do zainteresowania się przestrzenią historyczną, odniesieniem do czasu, w którym żyjemy, do zjawisk zachodzących w przeszłości i określających przyszłość. Jest to również sygnał alarmowy dla pedagogów i nauczycieli. Należy postawić pytanie o rolę edukatorów, ich zaangażowanie w ulepszanie świata. Jest to także pytanie o samoidentyfikację pedagogów - nauczycieli akademickich.

\title{
Słowa kluczowe:
}

przestrzeń publiczna, język wykluczający, alert dla pedagogów

\begin{abstract}
Culture is inseparable from language; language is a kind of cultural guide, it facilitates its understanding. Language is both a social bond for society and a tool of expression, and for the individual a powerful factor in the development of individuality. Hence the necessity to become interested in the language - invisible educational environment - by pedagogues. The space of education, considered here through the prism of language, remains in close connection with public space. Hence the need for insight into the public sphere and public discourse.

The transformation of Polish society in the 1990s revealed its internal diversity and what is connected with it - the need to find a language that would allow communication and description of a new reality without hurting anyone. However, the phenomenon of political correctness has not been approved in Poland. What's more, hate speech is increasing, language that excludes other social categories. This is a signal that encourages us to be interested in the historical space, reference to the time in which we live, to phenomena occurring in the past and defining the future. It is also an alarm signal for pedagogues and teachers. A question should be asked about the role of educators, their commitment to improving the world. It is also a question about self-identification of pedagogues-academic teachers.
\end{abstract}

\section{Keywords:}

culture-language-education, public space, excluding language, historical space, alert for educators

\section{WZAJEMNE ZWIĄZKI KULTURY, JĘZYKA I EDUKACJI}

W podjętej refleksji, raczej naszkicowanej aniżeli ukończonej, pragnę skoncentrować się na tym aktywnym czynniku kształtowania rzeczywistości, jakim jest język, na jego związkach z kulturą i edukacją. W dalszej części zwrócę uwagę na 
znaczenie języka w przestrzeni publicznej - będącej przestrzenią edukacji. Nawiązanie do konkretnej, polskiej przestrzeni publicznej będzie okazją przywołania myśli Heleny Radlińskiej, Anny Przecławskiej i Wiesława Theissa, wskazaniem znaczenia warstwy historycznej w wychowaniu. Artykuł zakończę rozważaniem o roli pedagogów społecznych i specjalnych (a może raczej pytaniem o tę rolę), o ich zadaniach w obecnej dobie, aktualnym czasie.

Na wstępie pragnę też zaznaczyć, że nie będę koncentrować się na jednej kategorii osób wykluczonych, aby nie narazić się na zarzut stosowania odmiany narcyzmu małych różnic, z którym mamy do czynienia, gdy każda grupa o określonej tożsamości wytwarza podgrupy i „,cechy specyficzne”. Christopher Hitchens, anglo-amerykański pisarz i publicysta, który używa tego sformułowania, ilustruje tendencję prześmiewczo: „grupa czirokeskich transgenderowych lesbijek z nadwagą i drugim stopniem niepełnosprawności domaga się wysłuchania”. Działania koncentrujące się na tak wąskich, wyspecyfikowanych kategoriach szybko zamieniają się z radykalnych w reakcyjne, twierdzi Hitchens (2017, s. 136).

Mówiąc o wzmożonej obecności języka ekskluzji w polskiej przestrzeni publicznej, chcę zwrócić uwagę na szeroko rozumianą przestrzeń edukacyjną i jej cechę: otwartości lub zamknięcia na Innego, Innego w różnych postaciach.

$* * *$

Wzajemne związki między językiem i kulturą były przedmiotem szczególnego zainteresowania językoznawców i filozofów niemieckich już od początku XIX w. oraz antropologów amerykańskich w XX wieku. Z badań tych wynika, że kultura jest nierozerwalnie związana z językiem. Już Wilhelm Humboldt podkreślał nietrwałość związku między myśleniem a językiem, uważał, iż w języku danego narodu odbija się światopogląd tego narodu, zatem język (który traktował jako działanie - energeia) trzeba rozpatrywać w bezpośrednim powiązaniu z kulturą i psychiką danego społeczeństwa (Guzik, 2003, s. 23).

Do twierdzeń tych nawiązywał Leo Weisgerber, twórca i przedstawiciel europejskiej szkoły neohumboldtyzmu. W jego przekonaniu język jest w pierwszym rzędzie duchowym czynnikiem kształtowania rzeczywistości (wirkende kraft), a dopiero na drugim miejscu narzędziem komunikacji myślowej. Uczony ten podkreślał również znaczenie języka ojczystego/macierzyńskiego² dla kształtowania sposobu widzenia świata.

2 Pojęcie język ojczysty używam zamiennie z pojęciem język macierzyński (macierzysty). Terminy „,język macierzyński” i „,język przyrodzony” były używane przez Karola Miarkę (1825-1882), 
Jak wskazuje Barbara Guzik, koncepcje szkoły europejskiej przypominają założenia teoretyczno-metodologiczne antropologicznej lingwistyki amerykańskiej, czyniącej przedmiotem badań wzajemne związki miedzy językiem a kulturą danej społeczności. Jednym z twórców tego nurtu był Edward Sapir; zafascynowany językiem, traktował go jak klucz do zrozumienia człowieka i jego myśli, kultury i rzeczywistości społecznej. Język postrzegał jako: 1) twór kulturowy i społeczny, 2) system symboliczny i ekspresyjny, 3) symbol solidarności społecznej ludzi mówiących danym językiem.

Język, w ujęciu Sapira, to „symboliczny przewodnik po kulturze” ułatwiający jej głębsze zrozumienie. Dla społeczeństwa to „siła konsolidująca i uniformizująca społeczeństwo”, „doskonałe narzędzie ekspresji i komunikacji we wszystkich społecznościach”. Natomiast dla jednostki to ,jeden z najpotężniejszych czynników rozwoju indywidualności” (Guzik, 2003, s. 24). Ostatnie ze sfomułowań, dotyczące jednostki, wskazuje - choć nie jest to wyrażone wprost - na funkcję edukacyjną języka.

Tu warto jeszcze przywołać nazwiska i wypowiedzi Benjamina Lee Whorfa, a także Charlesa Wrighta Millsa, którzy podjęli próby zastosowania idei Sapira i Wharfa do społeczeństw industrialnych. Stwierdził on: „Nasze zachowanie i percepcja, nasza logika i myślenie podlegają kontroli systemu językowego. Wraz z językiem nabywamy zespół norm i wartości” (za: Bokszański, Piotrowski, Ziółkowski, 1977, s. 26). Słynne, po wielokroć cytowane zdanie Ludwiga Wittgensteina brzmi: „Granice mojego języka oznaczają granice mojego świata” (za: Ziółkowski, 1998). Edward Twitchell Hall, zainspirowany pracami Sapira i Whorfa, w swojej pracy Ukryty wymiar zauważa: „Język jest czymś więcej niż tylko środkiem wyrażania myśli. W gruncie rzeczy stanowi on główny czynnik kształtujący myślenie”. A dla lepszego zobrazowania opisywanego związku porównał umysł człowieka do komputera: „Jak komputer, umysł człowieka może rejestrować i porządkować rzeczywistość tylko w zgodzie z programem” (Hall, 1976, s. 26).

polskiego działacza społecznego na Górnym Śląsku, nauczyciela, pisarza, publicystę, który położył wielkie zasługi dla budzenia świadomości narodowej Polaków. Miarka podkreślał znacznie języka macierzyńskiego jako podstawowego czynnika kształcenia ducha. Wykształcenie ducha (czyli rozumu, mądrości ludzkiej opartej na doświadczeniu i wiedzy usystematyzowanej) uznawał za jednakowo ważne z wykształceniem serca (głównymi czynnikami kształcenia serca były: matka, szkoła i Kościół) - wespół służyły osiągnięciu celu, który sformułował jako: doczesna i wieczna szczęśliwość. Swój program wychowawczy Miarka przedstawił w tekście Głos wołajq̨cego na puszczy górnoślq̨skiej, czyli o stosunkach ludu polskiego na Ślq̨sku, który ukazał się w 1865 r. w formie broszury. Wznowienia tej wersji, opatrzonego przedmową Andrzeja Brożka, dokonało Wydawnictwo Śląsk w 1984 r. (zob. Wójcik, 1991). 
Moje wcześniejsze zainteresowania i dociekania dotyczyły perspektywy rozwoju człowieka obdarzonego płcią kulturową, ze zwróceniem uwagi na marginalizowane w języku i - szerzej - kulturze kobiety. Stąd feministyczne analizy przestrzeni językowej. A ponieważ dyscyplina, z której się wywodzę, to pedagogika społeczna, przeto naturalnym jest sięgnięcie do Radlińskiej i jej pojęcia środowiska niewidzialnego. Owo środowisko niewidzialne oddziałuje, jak wskazywała, przez kontakty z wybitnymi ludźmi, twórcami nowych idei, kontakty bezpośrednie i pośrednie. Treści, które docierają do odbiorcy i są źródłem symboli, znaków tożsamości plemiennej, narodowej czy kulturowej, służących porządkowaniu świata, są przekazywane przy użyciu języka. Dlatego język (w różnych jego aspektach) jest, w moim przekonaniu, najważniejszym elementem środowiska niewidzialnego. A jednocześnie sam jest niewidzialny, w tym sensie, że jego znaczenie jest nieuświadamiane (a na pewno nie w takim stopniu, w jakim powinno być) przez pedagogów. O ile obrazy są wszechobecne i widoczne, stając się przedmiotem stałej uwagi odbiorców-widzów, o tyle język zdaje się być w zasięgu uwagi w mniejszym stopniu, zdaje się tracić na znaczeniu. Współcześnie środowisko niewidzialne jeszcze inaczej wymyka się uwadze osób, które powinny nad nim czuwać - schodzi do „drugiego obiegu”; mam na myśli media społecznościowe. Im intensywniej rozwija się ta postać sfery publicznej, tym bardziej powinna narastać czujność wobec tego i wrażliwość na to, co dzieje się w oficjalnej przestrzeni publicznej.

\section{SŁOWA W PRZESTRZENI PUBLICZNEJ. POPRAWNOŚĆ POLITYCZNA I MOWA NIENAWIŚCI - ODZWIERCIEDLENIE POLARYZACJI SPOŁECZNEJ WOBEC AKCEPTACJI INNEGO}

Mówiąc o przestrzeni publicznej, warto byłoby uściślić sam termin. Według definicji zawartej w polskiej ustawie o planowaniu i zagospodarowaniu przestrzennym ${ }^{3}$ przestrzeń publiczna to obszar o szczególnym znaczeniu dla zaspokajania potrzeb mieszkańców, poprawy jakości ich życia i - co jest istotne w kontekście prowadzonych tu rozważań - sprzyjający nawiązywaniu kontaktów społecznych ze względu na jego położenie oraz cechy funkcjonalno-przestrzenne ${ }^{4}$. Zdaniem niemieckiego

${ }^{3}$ Obwieszczenie Marszałka Sejmu Rzeczypospolitej Polskiej z dnia 13 maja 2016 r. w sprawie ogłoszenia jednolitego tekstu ustawy o planowaniu i zagospodarowaniu przestrzennym (Dz.U. z 2016 r. poz. 778).

${ }^{4}$ O istocie przestrzeni publicznej, definiowanej w kategoriach ekonomiczno-społecznych jako 
socjologa Jurgena Habermasa jednym z kluczowych pojęć, poprzez które można widzieć przestrzeń publiczną, jest publiczna jawność. To dzięki niej rozpowszechnione zostają różne punkty widzenia, a nie jedynie wąskie, uznaniowe (arbitralne) widzenie świata czy spraw społecznych. Habermas wyjaśnia, iż przestrzeń publiczna nie jest tożsama z komunikacją polityczną (z grą opina-media-politycy) - wykracza daleko poza nią. Przestrzeń publiczna zawiera wszystkie tematyki oraz wszystkie opinie, które, choć wygłoszone w sferze prywatnej, mogą osiągnąć poziom publiczny (Margaret, 2012). Do przestrzeni publicznej kwalifikują się zatem Internet (np. portale społecznościowe, komunikatory typu Skype, Gadu-Gadu, IRC itp.) lub inne środki masowego przekazu: gazety, radio i telewizja itp. Przestrzenią publiczną jest również sfera religijności (Margaret, 2012).

Organizacja przestrzeni publicznej, zarządzanie nią, wpływają na sposób kontaktowania się ludzi. Także na sposób doświadczania i postrzegania swoich praw obywatelskich, np. prawa do zrzeszania się. Nawiasem mówiąc, termin „obywatelstwo” zasługuje na to, żeby na chwilę się przy nim zatrzymać. Znakomicie unaocznia bowiem, że idea inkluzji/włączania współwystępuje z praktyką ekskluzji/wykluczania. Obywatelstwo - konceptualizowane zwykle w kategoriach uniwersalnych i abstrakcyjnych, jawi się jako konstrukcja pojęciowa ogólna i stosunkowo „obiektywna”. Ta pozbawiona kontekstu postać zwykle sytuowana jest w kategorii naród-państwo, co jednocześnie oznacza brak skupienia się na poszczególnych przestrzeniach, w których obywatelstwo zyskuje wymiar praktyczny, zauważa Elżbieta Oleksy. Tymczasem historia pokazuje, że bez względu na czas i miejsce idea włączenia jednostki poprzez obywatelstwo była zawsze związana z wykluczeniem. Tak było zarówno w przeszłości, jak i dzisiaj (Oleksy, 2008, s. 9-10) 5 .

Przedmiotem mojego zainteresowania jest edukacja, obszar działań praktycznych pedagogów oraz ich refleksji i badań. Przestrzeń edukacji interesuje

dobru strategicznym dla społeczności lokalnej, o jej użytkowaniu i dostępie do niej, o konieczności obrony społecznej różnorodności, unikaniu izolacji i segregacji oraz wspieraniu słabszych grup społecznych, jak również konieczności dbania o przestrzeń publiczną, jako prawa i obowiązku obywatelskiego, wypowiadają się urbaniści i przedstawiciele samorządów lokalnych. Przykładem: Karta Przestrzeni Publicznej adresowana do uczestników III Kongresu Urbanistyki Polskiej Związku Miast Polskich i Towarzystwa Urbanistów Polskich (ZMP i TUP), Poznań 2009.

${ }^{5}$ Gdy cały naród francuski ogłoszono równym, wyłączono z tego projektu kobiety. Z kolei wśród sygnatariuszy Konstytucji Stanów Zjednoczonych, obwieszczającej równe prawa dla wszystkich, byli właściciele niewolników. Dzisiaj obywatelem europejskim można być tylko wtedy, gdy jest się jednocześnie obywatelem kraju należącego do Unii Europejskiej. Tak więc procesy wyłączenia, które kształtowały historię europejską od zarania dziejów, powtarzają się na wielu poziomach - konstatuje Elżbieta Oleksy (2008, s. 9). 
mnie w jej aspekcie werbalnym i postrzegam ją w ścisłym związku z przestrzenią publiczną i narracją, jaka się w tej przestrzeni toczy. Co bowiem warte podkreślenia to to, że obie przestrzenie pozostają ze sobą we wzajemnej relacji, zatem i przynależne im narracje interferują miedzy sobą.

Gdy w latach 90. XX wieku w wyniku wielokrotnie złożonej transformacji polskie społeczeństwo zaczęło przeobrażać się, ujawniając wewnętrzne zróżnicowanie, pojawiło się też zagadnienie języka odpowiedniego do nowych potrzeb - termin politycznej poprawności. Socjolożka Kinga Dunin wyjaśniała, że poprawność polityczna zawiera nie tylko reguły uprzejmości, ale wiąże się z pewnym światopoglądem; wizja otwartości na różne potrzeby, style życie czy preferencje seksualne jest jednocześnie przeciwna nawoływaniu do represji ograniczających ludzką wolność. Dopowiadała, że za tym zjawiskiem stoi pewien projekt społecznej etyki, konkurencyjny wobec tradycyjnej moralności i wymagający uznania za poważne problemów przynależnych do sfery traktowanej jako prywatno-obyczajowa. Zastanawiała się, czy aby nie przydałaby się nam świadoma swych zasad rodzima polityczna poprawność (Dunin, 1996, s. 72).

Jednak pojęcie poprawności politycznej (PP), ang. political correctness (PC), od początku budziło silne negatywne emocje. Ze swoim amerykańskim rodowodem zjawisko postrzegano jako zagrażające naszej kulturze i wolności, oceniano w kategoriach irracjonalności, śmieszności. Jeden z łagodniejszych krytyków PP historyk idei Marcin Król w połowie lat 90. XX wieku twierdził, że nam Polakom wystarczy zwykła przyzwoitość. Andrzej Siciński, znakomity badacz zasłużony dla rozwoju problematyki obywatelstwa, postawił niemal znak równości pomiędzy „tzw. (podkr. E.G.) poprawnością polityczną” a „przekonaniem, że akceptować należy jedynie standaryzację, przeciętność” (Siciński, 2004, s. 21). A sama Dunin została opatrzona (przez Cezarego Michalskiego) mianem ideologicznej manipulatorki języka, która zachęca do totalnej wojny cywilizacyjnej (Dunin, 1996, s. 73).

Poprawność polityczna nie doczekała się zmiany nastawienia. W pierwszych latach XXI wieku Marek Ostrowski, dziennikarz opiniotwórczego tygodnika „Polityka”, pisał, że w Polsce pojęcie to nie zrobiło kariery, wręcz przeciwnie - wywołuje ironiczne komentarze. Podczas gdy w jego przekonaniu „[...] »polityczna poprawność« to tylko troska, by komuś niepotrzebnie nie robić przykrości” (Ostrowski, 2003, s. 28-29). Spostrzeżenie Ostrowskiego o ironicznych komentarzach nie straciło na aktualności, czego potwierdzeniem jest najnowsza wypowiedź Pawła Lisickiego, redaktora naczelnego tygodnika „Do Rzeczy”. Z entuzjazmem odnotowuje on wielką swobodę Polaków w wyrażaniu swoich poglądów, co odróżnia Polskę od innych krajów: „W wielu państwach zachodnich, 
za sprawą różnej maści feministek, ruchów LGBT, antyrasistów i antyfaszystów, trockistów i maoistów, prawdziwe spory ideowe są już niemal niemożliwe. Nie wolno publicznie twierdzić, że aborcja jest zbrodnią na nienarodzonym, związki homoseksualne są przeciw naturze, a islam propaguje przemoc. W ogóle coraz mniej wolno, a policja myśli (wyr. E.G., zapewne chodzi tu o poprawność polityczną) panoszy się coraz bardziej” (Polityka, 2018, s. 98).

Na ile radość ze swoiście rozumianej wolności słowa jest uzasadniona? Jakie są jej skutki? I jaki jest sam język tej konkretnej wypowiedzi? Osoba zainteresowana badaniem werbalnej przestrzeni edukacji i tym samym przestrzeni publicznej ma duże pole do studiowania.

Na zakończenie tej części rozważań warto przypomnieć, że Kinga Dunin, wypowiadając się jako zwolenniczka poprawności politycznej i będąc zaangażowaną w piętnowanie antykobiecych stereotypów oraz bezrefleksyjnego antyfeminizmu w języku, przywołała w połowie lat 90 . XX wieku, głos Stanleya Fisha (określając go mianem wyroczni PC). Ten zaś jako przykład udanego działania, ogromnej pracy, jaką wykonano w całym cywilizowanym świecie po drugiej wojnie światowej, podał Żydów i wyrugowanie antysemityzmu z języka (Dunin, 1996, 69-75). Ten budujący przykład miał wskazywać kierunek działania i umacniać przekonanie o skuteczności pracy edukacyjnej.

\section{NASILENIE JĘZYKA WYKLUCZAJĄCEGO W PRZESTRZENI PUBLICZNEJ - NIEOCZEKIWANY „WKŁAD” W OBCHODY 100. ROCZNICY ODZYSKANIA NIEPODLEGŁOŚCI PAŃSTWA POLSKIEGO}

Helena Radlińska już na początku swojej naukowej działalności sytuowała pedagogikę społeczną w kręgu teorii pedagogiki humanistycznej, skupionej na problemach człowieka i środowiska jego życia. Nadrzędnym celem budowanej przez siebie dyscypliny naukowej uczyniła rozwijanie „sił ludzkich”, „sił działalnych”, widzialnych i utajonych, dynamiki zdolnej do zmieniania rzeczywistości. Miała temu służyć edukacja, to za jejpośrednictwem Radlińska pragnęła budować rzeczywistość, w której będą respektowane prawa demokracji (Przecławska, Theiss, 1996, s. 23).

Nie pora tu ani miejsce na historyczny wgląd w przeszłość, na analizę krótkiego czasu niepodległego bytu państwowego II RP, którego setną rocznicę odzyskania świętujemy przez cały 2018 rok. Poprzestańmy jedynie na eufemistycznej konsta- 
tacji, że prawa demokracji nie były w pełni respektowane, zwłaszcza w latach 30. $\mathrm{XX}$ wieku$^{6}$ a dyskurs wykluczający był silnie obecny w przestrzeni publicznej ${ }^{7}$.

Przestrzeń historyczna jest jednym z ważnych wymiarów przestrzeni, na przecięciu których kształtuje się los człowieka, podkreśla Anna Przecławska (autorka wymienia jeszcze przestrzenie: fizyczną, społeczną, symboliczną i temporalną, w której szczególne miejsce zajmuje wymieniona przestrzeń historyczna) (Przecławska, 1999, s. 76).

O znaczeniu historii dla rozwoju człowieka pisze także Timothy Snyder ${ }^{8}$ w tekście Historia i wolność - epilogu rozprawy pt. O tyranii. Dwadzieścia lekcji z dwudziestego wieku (powstałym w grudniu 2016 roku i skierowanym do obywateli Stanów Zjednoczonych). Zauważa on, że zapomnieliśmy o historii i przestrzega: „Jeżeli chcemy potwierdzić nasze przywiązanie do wolności, musimy przywrócić porządek w naszym poczuciu czasu” (Snyder, 2017, s. 120). Snyder wskazuje dwa antyhistoryczne spojrzenia na przeszłość i płynące stąd konsekwencje: 1) myślenie w kategoriach nieuchronności, 2) myślenie w kategoriach wieczności.

To pierwsze, związane z przekonaniem że traumatyczne doświadczenia faszyzmu, nazizmu i komunizmu są na tyle odległe, że już nieistotne, niesie konkluzję nieuchronności biegu historii w jednym kierunku - w stronę demokracji liberalnej. Po upadku komunizmu w Europie Wschodniej w latach 1989-1991 narodził się mit o „końcu historii”. Teraźniejszość zaczęła być postrzegana tylko jako krok w kierunku przyszłości, którą już znamy - postępującej globalizacji, coraz powszechniejszego racjonalizmu i rosnącego dobrobytu. Tego typu myślenie to pogrążanie się na własne życzenie w śpiączce intelektualnej, zauważa Snyder (2017, s. 121)

Drugie spojrzenie na przeszłość pozornie bierze ją pod uwagę, ale tak naprawdę jest całkowicie pochłonięte sobą i nie przejmuje się faktami. Przeszłość to rozległy, mglisty dziedziniec pełen pomników narodowego męczeństwa. Najpełniejszym wyrazem tego spojrzenia jest tęsknota za chwilami, które w istocie nigdy się nie wydarzyły. Co więcej, każde odniesienie do przeszłości wydaje się związane z zakusami zewnętrznego wroga na narodową czystość, konstatuje przywołany autor (2017, s. 123-124).

${ }^{6}$ Szerzej rzecz ujmując należy zauważyć, że w latach 20. i 30. demokracje europejskie poddały się prawicowemu autorytaryzmowi i faszyzmowi (Snyder, 2017, s. 11).

7 Pouczającą lekturą może być praca Ronalda Modrasa: Kościół katolicki i antysemityzm w latach 1933-1939, Wydawnictwo homini, Kraków 2004.

8 Profesor Uniwersytetu w Yale, specjalizujący się we współczesnych dziejach Europy Środkowej i Wschodniej oraz w historii nowożytnego nacjonalizmu. 
Ilustracją wskazanego sposobu myślenia w Polsce mogą być ustawa o nowelizacji ustawy o IPN (podpisana przez Prezydenta RP w lutym 2018 roku) oraz liczne, powtarzające się w różnym czasie kontestacje faktów historycznych dotyczących traktowania Żydów przez Polaków (sprawa Jedwabnego). Na temat głęboko zakorzenionego antysemityzmu polskiego społeczeństwa, wynikającego z wielowiekowej nauki Kościoła i wielkiego wysiłku polskich nacjonalistów, wypowiada się Jan Grabowski - historyk, członek Zespołu Centrum Badan nad Zagładą Żydów przy IFiS PAN. Zauważa, że „pierwsze dekady XX w. przerodziły nienawiść w ideologię nie tylko religijną, lecz również rasistowską i pseudonaukową" (Czarnecka, 2018, s. 24). Grabowski, mówiąc o trudności przebicia się do świadomości (on sam mówi o podświadomości) wiedzy historycznej, podaje przykład badań, które przeprowadzono w 2015 roku. Uczniów klas ponadgimnazjalnych zapytano, co się stało w Jedwabnem 46\% odpowiedziało, że Niemcy zabili tam Polaków ratujących Żydów; 25\%, że Niemcy i Rosjanie wymordowali tam polskich oficerów (Czarnecka, 2018, s. 24).

Należy zauważyć, że ów nienawistny język, skierowany wobec Polaków żydowskiego pochodzenia (i szerzej - społeczności żydowskiej) jest najnowszą odsłoną języka ekskluzji - stale obecnego (choć z różnym nasileniem) w przestrzeni publicznej, począwszy od lat 90. XX wieku. Wówczas miał charakter rasistowski i skrajnie nacjonalistyczny. Jego aktualnym odbiciem był Marsz Niepodległości, który 11 listopada 2017 roku przeszedł ulicami Warszawy9 . W latach 2013-2014 przestrzeń publiczną, z intensywną obecnością przestrzeni kościołów, opanowała mowa pełna nienawiści i poniżenia wobec gender, wykreowanego zła, które na potrzeby nieprzygotowanych i nieznających pojęcia odbiorców (czyli ogromnej większości społeczeństwa) określono „ideologią gender” oraz „genderyzmem”. W latach 2015-2016 pojawili się nowi wykluczeni - choć nieobecni fizycznie w Polsce, okazali się „dobrym” obiektem nienawistnej mowy - syryjscy uchodźcy. Generalnie wszyscy uchodźcy, zwłaszcza przedstawiciele innej religii.

„Nasłuchuj niebezpiecznych słów” - to jedna z dwudziestu lekcji Timothy’ego Snydera. „Zwracaj uwagę na pojawienie się terminów »ekstremizm« i »terroryzm «. Bądź wyczulony na hasła »zagrożenie« i »wyjątek « - są śmiertelnie niebezpiecz-

${ }^{9}$ Wśród haseł pojawiły się nawoływania rasistowskie, wulgarne i ksenofobiczne. Na transparentach - krzyże celtyckie, jeden z najważniejszych symboli neofaszystów i głosicieli ideologii supremacji białej rasy, wykorzystywany obecnie jako zastępstwo zakazanej swastyki. Sfotografowano także członków ONR z transparentami głoszącymi: „Europa tylko biała”, „Czysta krew”, „Biała Europa braterskich narodów”.

https://www.wprost.pl/kraj/10086084/faszystowskie-hasla-i-symbole-na-marszu-niepodleglosci-w-warszawie-i-na-wiecu-we-wroclawiu.html [dostęp: 20.03.2018] 
ne”, przestrzega cytowany autor. „Okazuj gniew, gdy ktoś podstępnie sięga do patriotycznego leksykonu” (Snyder, 2017, s. 99). Trafne jest spostrzeżenie historyków i socjologów, że sięganie po mityczną przeszłość, po historię tworzoną na bieżące potrzeby, pozwala odwrócić uwagę od trudnych spraw teraźniejszości i możliwej przyszłości, od rzeczywistych problemów i ich rozwiązań, od potrzeby samodoskonalenia.

Nie ulega wątpliwości, że w dobie akceptacji autorytaryzmu w Polsce (zauroczenia siłą, widocznego bardziej wśród młodych niż starszych - co źle rokuje na przyszłość) potrzebna jest wizja ładu społecznego (i szerzej: społeczno-politycznego i gospodarczego), odwołująca się do odczuwanego powszechnie poczucia sprawiedliwości ${ }^{10}$, kierowana do autonomicznych jednostek mających poczucie podmiotowości i świadomych wspólnego celu. I niewątpliwie potrzebni są też liderzy (owe siły jednostkowe, przodownicze, używając języka Radlińskiej), zdolni porwać do realizacji kreślonych wizji zindywidualizowaną społeczną wielość, gotowi wziąć odpowiedzialność za oblicze świata ${ }^{11}$. Czy w ich gronie mogą (powinni) znaleźć się pedagodzy?

10 Jak pokazują badania Krystyny Skarżyńskiej, prowadzone w okresie ostatnich kilkunastu lat (od 2004 r.), porządek społeczno-polityczny w Polsce miał słabą legitymizację moralną. W październiku 2014 r. tylko niespełna 10\% badanych twierdziło, że polskie prawo jest równe i sprawiedliwe dla wszystkich, 20\% uważało, że instytucje państwowe na ogół dobrze służą obywatelom (w 2016 r. wskaźnik ten zmalał do 12,1\%), a 16,1\% oceniało porządek społeczny za sprawiedliwy. Edwin Bendyk podsumowuje badania stwierdzeniem: „Polacy w swej masie, pomimo zadowalających wyników makroekonomicznych, malejącego bezrobocia i postępującej infrastrukturalnej modernizacji, uznawali ład społeczno-polityczny i ekonomiczny za niesprawiedliwy“. Inne badania prof. Skarżyńskiej wykazały wysoki poziom akceptacji prawicowego autorytaryzmu; co zaskakujące - skłonność do akceptacji bardziej odpowiada młodym niż starszym. (Bendyk, 2018, s. 25-27).

11 Jedna z dwudziestu lekcji, jakie niesie historia - historia dwudziestego wieku, do której odniósł się Timothy Snyder, brzmi: Weź odpowiedzialność za oblicze świata. Autor zwraca uwagę na znaczenie symboli, na to, że symbole dnia dzisiejszego umożliwiają nastanie rzeczywistości jutra. I wzywa: „Zwracaj uwagę na swastyki i inne oznaki nienawiści. Nie odwracaj wzroku i nie przyzwyczajaj się do nich. Usuwaj je sam i dawaj przykład innym” (Snyder, 2017, 33).

W tym kontekście warto przypomnieć wypowiedź Radlińskiej, sprzed niemal stu lat; wzywała do współodpowiedzialności pokolenie, które odzyskało niepodległość swojego kraju w 1918 r. Pisała wówczas: „Trzeba, żeby [...] jak Polska długa i szeroka - ludzie się czuli obywatelami współodpowiedzialnymi za losy wszystkich. Żeby u obcych słowo Polak: budziło szacunek i życzliwość” (Radlińska, 1925, 6, s. 21-22). 


\section{ALERT DLA PEDAGOGÓW, CZYLI DLA KOGO? REFLEKSJA NAD SAMOIDENTYFIKACJĄ I ROLĄ PEDAGOGÓW SPOŁECZNYCH ORAZ PEDAGOGÓW SPECJALNYCH - NAUCZYCIELI AKADEMICKICH}

Obserwatorzy życia publicznego i przestrzeni publicznej w minionym okresie (za cezurę przyjmuję rok 1989) mogli odnotować wiele zjawisk niepokojących, a nawet groźnych, niepożądanych z punktu widzenia bezpieczeństwa i zdrowia obywateli, związanych z obecnością Innego. Niemal każda dyskusja na ich temat kończy się stwierdzeniem o potrzebie edukacji, o zadaniach dla edukacji - dla pedagogów, nauczycieli.

Proponując użycie terminu alert, sięgam do słowników w celu uściślenia znaczenia tegoż. Nie znajdując go w słownikach pedagogicznych (Okonia, Leksykonie PWN Pedagogika pod red. Milerskiego i Śliwerskiego, Elementarnych pojęciach pedagogiki społecznej i pracy socjalnej), opieram się na Słowniku języka polskiego $P W N$, gdzie czytam (red. M. Szymczak, 1999, s. 30) ${ }^{12}$ wyjaśnienie: „stan gotowości do akcji zespołowej, zwykle w organizacjach młodzieżowych, alert harcerski, ogłosić alert”'13.

Powyższa definicja uzmysławia, że użyte pojęcie nie jest jednak właściwe. Nie chodzi bowiem o akcję ani w ogóle działania akcyjne, przeciwnie - potrzebne jest działanie systematyczne, permanentne, przemyślane, celowe. Warto zatrzymać się też przy drugim członie definicji, pojęciu: zespołowe. Skłania ono do zastanowienia się kto - w odniesieniu do środowiska pedagogów - miałby tworzyć ów zespół. Czy pedagodzy, przedstawiciele pedagogiki społecznej i specjalnej są gotowi do zespołowego, wspólnego działania? Którzy pedagodzy powinni najsilniej odczuwać zobowiązanie do kontestowania dyskursu wykluczania i szerzej - do zaangażowania, włączenia się zarówno w dyskurs na temat inkluzji, jak i podjęcia działań zmieniających rzeczywistość?

Czy pedagodzy społeczni, którzy od początku rozwoju dyscypliny zainteresowani byli ludźmi marginalizowanymi i wykluczanymi, czy pedagodzy specjalni - z podobnych powodów a może andragodzy lub przedstawiciele pedagogiki

${ }^{12}$ W pierwszym z wymienionych znaczeń to „stan międzynarodowego pogotowia obserwacyjnego w okresie wzmożonej aktywności Słońca, silnych zaburzeń magnetycznych, itp.”

13 Bardziej odpowiednie wydaje się znaczenie pojęcia alert zamieszczone w Wielkim Słowniku Angielsko-Polskim PWN-Oxford (2002, s. 28), gdzie słowo to (ang. alert) tłumaczone jest jako stan pogotowia, pogotowie, alarm; być w pogotowiu; zwracać baczną uwagę na coś; ogłosić stan pogotowia; w znaczeniu czasownikowym: to alert - ostrzec kogoś przed czymś; uczulić kogoś na coś, uświadomić komuś coś. 
międzykulturowej? Praktycy czy teoretycy ${ }^{14}$ : przy okazji seminariów, konferencji, zjazdów, kongresów. Jaki charakter miałoby mieć to działanie? Apeli i odezw płynących ze środowisk naukowych ${ }^{15}$, a może projektów badawczych ${ }^{16}$ ?

Pytanie to wyłoniło się po lekturze wywiadu, jaki przeprowadził Tomasz Sosnowski z prof. Tadeuszem Pilchem, który to wywiad ukazał się w czasopiśmie „Parezja”. Pada w nim pytanie: „Czy [...] w naturę nauczyciela, w szczególności nauczyciela akademickiego, czyli praktyka i teoretyka, jest wpisane czy powinno być wpisane doświadczenie irytacji, które może stanowić początek pewnej zmiany o charakterze pozytywnym - idącej w kierunku aktywności i określonych działań?” (Pilch, Sosnowski, 2016, s. 99). Odpowiedzią jest potwierdzenie i uzasadnienie: „Uważam, że [w - dop. E.G.] powołanie nauczyciela, w szczególności nauczyciela akademickiego, wpisana jest melioracja świata, jego udoskonalanie - jak to nazywał Aleksander Kamiński” [podkr. E.G.].

14 Snyder zwraca uwagę, że wolne zawody mogą wykształcić formy dialogu etycznego, który nie jest możliwy między odosobniona jednostką a odległym rządem. „Jeżeli wykonujący te zawody myślą o sobie jako o grupach posiadających wspólne interesy i zobowiązanych do nieustannego przestrzegania pewnych norm i zasad, daje im to pewność siebie, a w pewnym zakresie także i władzę” (Snyder, 2017, s. 41).

15 Przykłady podejmowanych działań to: list otwarty środowiska naukowego pedagogów zajmujących się problematyką gender z lutego 2014 r. (https://www.spoleczenstwoobywatelskie. gov.pl/sites/default/files/list_otwarty_pedagogow_w_sprawie_gender.pdf); manifest etnologów i antropologów polskich przeciw dyskryminacji z listopada 2016 r., podpisany przez uczestników Nadzwyczajnego Zjazdu Etnologów i Antropologów Polskich w Poznaniu (https://zjazd.weebly. com); działania Ruchu Pedagogów Społecznie Zaangażowanych, m.in. głos wsparcia kierowany do protestujących Matek i Rodziców Niepełnosprawnych Dzieci z wyrazami solidarności, wsparcia i szacunku. Biuletyn Stowarzyszenia nr 6 (8) 2018; akcja pod hasłem „Podaruj książkę politykowi może przeczyta choćby spis treści”, podjęta zamiast listu protestacyjnego - w odpowiedzi na słowa premiera Morawieckiego (podczas spotkania z korespondentami zagranicznych mediów w Muzeum Polaków Ratujących Żydów w Markowej) o zmarnowaniu 25 lat Polski dla wyjaśnienia naszej historii. Badacze dziejów postanowili zamanifestować swoją obecność i z humorem pokazać brak zgody na instrumentalne traktowanie historii (Historycy uzupełniają bibliotekę premiera. Polityka 2018, 7, s. 9).

16 Przykładem przedsięwzięcia badawczego może być projekt pn. „STOP seksistowskiej mowie nienawiści” realizowany wspólnie przez Ośrodek Badań nad Mediami Uniwersytetu Pedagogicznego w Krakowie wespół z Fundacją Autonomia. Rozpoczęty w styczniu 2018 r. będzie realizowany do końca maja 2018. Ma na celu podniesienie świadomości dotyczącej form, rodzajów i skali seksistowskiej mowy nienawiści (SMN) w przestrzeni publicznej (w tym w Internecie) oraz wypracowanie strategii reagowania na nią, zarówno w perspektywie indywidualnej, jak i - w miarę możliwości - prawnej instytucjonalnej. Badacze, jak mówią, mają nadzieję spowodować ograniczenie seksistowskiego hejtu (http://badania-media.up.krakow.pl/index.php/pl/ http://www.autonomia.org. pl/index.php?menu=24) [dostęp: 21.03.2018]. 
Pytanie kolejne, jakie wyłania się w tej sytuacji i które pragnę poddać pod rozwagę, brzmi: jak mają się do siebie melioracja świata (i w jakiej postaci) i... przedsiębiorczość intelektualna (Kwiatkowski, 2000, s. 15-16) ${ }^{17}$. Ta przedsiębiorczość, która jest coraz bardziej widoczna i ceniona w świecie nauki; wręcz - oczekiwana. Andrzej Kasperek, odnosząc się do terminu ukutego przez Roberta Chię oraz jego interpretacji dokonanej przez Stefana Kwiatkowskiego (kreślącego portret współczesnego przedsiębiorcy, działającego w świecie rozmytych granic pomiędzy nauką a biznesem), zauważa, że w rozważaniach poświęconych przede wszystkim biznesowi i nauce dość trudno znaleźć miejsce dla tej ludzkiej aktywności, która nie służy wzrostowi materialnego dobrobytu (Kasperek, 2004, s. 48-49). Stwierdza też, że coraz więcej jest sposobności, aby niegdysiejszy intelektualista przeistoczył się w rączego przedsiębiorcę, odkrywając komercyjny, rynkowy wymiar własnej symbolicznej aktywności. Wymogom gry rynkowej coraz wyraźniej podlegają kolejne wymiary życia społecznego, także światy symboliczne eksplorowane przez człowieka, konstatuje Kasperek.

Czy zatem skłonni są buntować się, polemizować, poddawać krytyce, przeciwstawiać się, występować z protestem, innymi słowy - angażować się w procesy i zjawiska z przestrzeni publicznej ci tu myślę o pedagogach-nauczycielach akademickich, którzy są częścią machiny tworzenia utowarowionej wiedzy, jak to określił Michael Burawoy w swojej mowie prezydenckiej ${ }^{18}$. Zauważył on, że mechanizmy regulacji (drastycznie obecne, obowiązujące w edukacji wyższej) i komercjalizacji wzmagają rywalizację między osobami, wydziałami, uniwersytetami. I jednocześnie odciągają od spraw publicznych, nie zostawiają miejsca na zaangażowanie w sprawy o istotnym społecznym znaczeniu (Burawoy, 2004). Wycofanie się uczonych (humanistów) z roli intelektualisty, unikanie zabierania głosu w dyskusjach dotyczących trudnych spraw wspólnoty obywatelskiej czy narodowej zdaje się wynikać z przekonania, że przedstawiciel świata nauki nie powinien mieszać się do polityki. Problem polega na tym, że sam świat nauki stał się kulturą korporacyjną, która promuje zestaw cnót i cech niemających wiele

17 Początkowo pojęcie to odnosiło się do praktykowania przez nauczycieli akademickich wysiłków pobudzania przedsiębiorczej wyobraźni studentów. Kwiatkowski interpretuje kategorię przedsiębiorczości intelektualnej jako zmodyfikowaną wersję kategorii przedsiębiorczości kapitalistycznej.

18 M. Burawoy, profesor Uniwersytetu Kalifornijskiego w Berkely, w 2004 r. objął funkcję prezydenta American Sociological Association (ASA); wygłosił wówczas przemówienie pt. O socjologię publicznq. Pomysł socjologii publicznej zaszczepił na gruncie amerykańskim, a następnie międzynarodowym (w latach 2010-2014 pełnił funkcję prezydenta International Sociological Association, ISA). 
wspólnego z etosem akademickim (Nawrocki, 2016, s. 65). Jak zauważa Radosław Nawrocki: „Świat reguł korporacyjnych i świat akademicki [...] nie zazębiają się ani nie uzupełniają. Obydwa te światy zderzone ze sobą wykrzywiają swoje obrazy, czyniąc z siebie nawzajem twory karykaturalne” (Nawrocki, 2016, s. 65). Dlatego sam świat uniwersytetu potrzebuje upolitycznienia, w sensie walki politycznej podjętej w obronie podstawowych wartości humanistycznych (Nawrocki, 2016, s. 71-72).

\section{Bibliografia}

Bendyk, E. (2018, 14-20 lutego). Siłą zdobyci. Polityka, 7(3148), s. 25-27.

Bokszański, Z., Piotrowski, A., Ziółkowski, M. (1977). Socjologia języka. Warszawa: Wiedza Powszechna.

Brodowska, H. (1979). Wstęp. W: H. Radlińska (red.), Oświata i kultura wsi polskiej. Wybór pism. Warszawa: Ludowa Spółdzielnia Wydawnicza.

Burawoy, M. (2004). O socjologię publicznq. Przemówienie prezydenckie z roku 2004. Pobrane z: http://www.burawoy.berkely.edu/PS/Translations/Poland/SA.Polish.pdf.

Czarnecka, K. (2018, 14-20 lutego). Ukryte w niepamięci. Rozmowa z prof. Janem Grabowskim o faktach dotyczących Zagłady na terenach Polski. Polityka, 7(3148), s. 22-24.

Dunin, K. (1996). Walka o język. W: K. Dunin, Tao gospodyni domowej (s. 69-74). Warszawa: Open.

Guzik, B. (2003). Powinnościowy model języka w dyskursie edukacyjnym. Kraków: Wydawnictwo Naukowe Akademii Pedagogicznej w Krakowie.

Hall, E.T. (1976). Ukryty wymiar. Tłum. T. Hołówka. Warszawa: PIW.

Historycy uzupełniają bibliotekę premiera (2018, 14-20 lutego). Polityka, 7(3148), s. 9.

Hitchens, Ch. (2017). Listy do młodego kontestatora. Tłum. D. Żukowski. Kraków: Karakter.

Kasperek, A. (2004). Kulturowy wymiar przedsiębiorczości. Esej o człowieku aktywnym. Chorzów: Oficyna Wydawnicza Górnośląskiej Wyższej szkoły Przedsiębiorczości im. Karola Goduli.

Kwiatkowski, S. (2000). Przedsiębiorca indywidualny. Warszawa: PWN.

Lalak, D., Pilch, T. (red.). (1999). Elementarne pojęcia pedagogiki społecznej i pracy socjalnej. Warszawa: Wydawnictwo Akademickie Żak.

Linde-Usiekniewicz, J. (red.). (2002). Wielki słownik angielsko-polski PWN-Oxford. Warszawa: Wydawnictwo Naukowe PWN.

Maigret, E. (2012). Socjologia komunikacji i mediów. Pobrane z: https://pl.wikipedia.org/ wiki/Przestrze\%C5\%84_publiczna.

Milerski, B., Śliwerski, B. (red.). (2000). Pedagogika. Leksykon PWN. Warszawa: Wydawnictwo Naukowe PWN.

Modras, R. (2004). Kościół katolicki i antysemityzm w latach 1933-1939. Kraków: Wydawnictwo homini. 
Nawrocki, R. (2016). Zaczarowany umysł w odczarowanej rzeczywistości. Rzecz o irytacji młodego pedagoga. Parezja, 2, s. 61-73.

Okoń, W. (1996). Nowy słownik pedagogiczny. Warszawa: Wydawnictwo Żak.

Oleksy, E. (2008).Wprowadzenie. W: E. Oleksy (red.), Tożsamość i obywatelstwo w społeczeństwie wielokulturowym (s. 7-21). Warszawa: Wydawnictwo Naukowe PWN.

Ostrowski, M. (2003, 4 stycznia). Bądź pobłażliwy. Polityka, 1(2382), s. 28-29.

Pilch, T., Sosnowski, T. (2016). Pedagogiczne irytacje. O potrzebie zaangażowania pedagogów w badania i przeciwdziałanie zjawiskom irytującym. Tadeusz Pilch w rozmowie z Tomaszem Sosnowskim. Parezja. Czasopismo Forum Młodych Pedagogów przy Komitecie Nauk Pedagogicznych PAN, 2, s. 91-101.

Polityka i Obyczaje (2018, 28 lutego-6 marca). Polityka, 9(3150), s. 98.

Przecławska, A. (1999). Przestrzeń życia człowieka - między perspektywą mikro a makro. W: A. Przecławska, W. Theiss (red.), Pedagogika społeczna. Pytania o XXI wiek. Warszawa: Wydawnictwo Akademickie Żak.

Przecławska, A., Theiss, W. (1996). Pedagogika społeczna: nowe zadania i szanse. W: A. Przecławska (red.), Pedagogika społeczna. Kręgi poszukiwań. Warszawa: Wydawnictwo Żak.

Radlińska, H. (1925). Do czego dążymy. Poradnik dla Gospodyń Wiejskich. Dodatek dwutygodniowy do Poradnika Gospodarstw Wiejskich, 6, s. 21-22. W: H. Radlińska (1979). Oświata i kultura wsi polskiej. Wybór pism (s. 302-305). Warszawa: Ludowa Spółdzielnia Wydawnicza.

Siciński, A. (2004). Europejskie społeczeństwo obywatelskie: instytucje i kultura. W: P. Gliński, B. Lewenstein, A. Siciński (red.), Samoorganizacja społeczeństwa polskiego: III sektor i wspólnoty lokalne w jednoczq̨cej się Europie. Warszawa: Wydawnictwo IFiS PAN.

Snyder, T. (2017). O tyranii. Dwadzieścia lekcji z dwudziestego wieku. Tłum. B. Pietrzyk. Kraków: Znak Horyzont.

Szymczak, M. (red.). (1999). Słownik języka polskiego PWN. Warszawa: PWN.

Wójcik, M. (1991). Program wychowania rodzinnego Karola Miarki. W: B. Żechowska (red.), W kręgu problematyki i metod polskiej pedagogiki. Katowice: Wydawnictwo Uniwersytetu Śląskiego.

Ziółkowski, M. (1998). Język i komunikowanie. W: Encyklopedia socjologii. T. 1. Warszawa: Oficyna Naukowa.

http://badania-media.up.krakow.pl/index.php/pl/.

http://www.autonomia.org.pl/index.php?menu=24.

https://pl.wikipedia.org/wiki/Przestrze\%C5\%84_publiczna. 